\title{
PERAN REGULASI DIRI ISLAMI DAN KARAKTERISTIK PEKERJAAN TERHADAP KOMITMEN ORGANISASIONAL PADA KARYAWAN ORGANISASI SYARIAH
}

\author{
Ugung Dwi Ario Wibowo \\ Fakultas Psikologi Universitas Muhammadiyah Purwokerto \\ Email: ugungs@yahoo.com
}

\begin{abstract}
Sharia organization founded in order to realize fallah (the common good), had a classic probems that is employees turnover problem. By that case, researcher interested in studying the role of islamic self-regulation and job characteristic on organizational commitment to the employees of sharia organization. Quantitative research study was classified based on the type of data and data analysis procedures. The independent variables in this study are: islamic self-regulation and job characteristic, while the dependent variable in this study is: organizational commitment. The subjects in this study were 44 employees in BMT. Hypothesis testing with multiple regression analysis, which data analysis calculate using SPSS For Windows Release 17.00 programme. Conclusions from this research are: (1) islamic self-regulation had significant effect on organizational commitment, (2) job characteristic had significant effect on organizational commitment, and (3) islamic self-regulation and job characteristic had simultant significant effect on organizational commitment.
\end{abstract}

Keywords: islamic self-regulation, job characteristic, organizational commitment, sharia organization

\begin{abstract}
Abstrak
Organisasi syariah didirikan dalam rangka mewujudkan fallah (kesejahteraan bersama) tidak luput terjadi turn-over karyawan sebagai dampak alamiah suatu organisasi. Untuk itu, peneliti tertarik untuk meneliti peran regulasi diri Islami dan karakteristik pekerjaan terhadap komitmen organisasi pada karyawan organisasi syariah. Penelitian ini tergolong penelitian kuantitatif berdasarkan jenis data dan prosedur menganalisis datanya. Variabel independen dalam penelitian ini yaitu: regulasi diri islami dan karakteristik pekerjaan, sementara variabel dependen di penelitian ini yaitu: komitmen organisasional. Subyek dalam penelitian ini adalah 44 karyawan BMT. Uji hipotesis menggunakan analisis regresi ganda yang dalam proses penghitungannya analisis data peneliti menggunakan program SPSS For Windows Release 17.00. Simpulan dari penelitian ini yaitu: (1) ada pengaruh yang signifikan antara regulasi diri islami terhadap komitmen organisasional; (2) tidak ada pengaruh yang signifikan antara karakteristik pekerjaan terhadap komitmen organisasional; dan (3) ada pengaruh yang signifikan antara regulasi diri islami dan karakteristik pekerjaan terhadap komitmen organisasional.
\end{abstract}

Kata kunci: regulasi diri islami, karakteristik pekerjaan, komitmen organisasi, organisasi syariah 
B elajar dari krisis ekonomi global pada tahun 1998 dan 2008, pola kerja pada organisasi industri telah bergeser dari bekerja secara individual menjadi bekerja secara teamwork (kerja tim) dan network (berjejaring). Penataan sumber daya manusia yang dimiliki dilakukan dengan melakukan berbagai inovasi guna mengantisipasi terjadinya resiko krisis dan persaingan dalam meraih konsumen yang semakin ketat, termasuk pelaku ekonomi syariah.

Dengan era keterbukaan dan arus informasi tentang hukum Islam dan kesyariahan di Indonesia yang mayoritas penduduknya beragama Islam, maka lembaga keuangan syariah semakin diminati banyak nasabah. Pada sektor finansial, persaingan antar lembaga keuangan syariah selain terjadi di berbagai level lembaga keuangan dan jenis layanan keuangan. Pada layanan perbankan syariah misalnya, secara umum pertumbuhan perbankan syariah di Indonesia 2002-2012 mencapai 40\% dengan jumlah layanan perbankan syariah di Indonesia saat ini terdiri atas: 11 bank umum syariah (BUS), 23 unit usaha syariah (UUS), dan 156 bank perkreditan rakyat syariah (BPRS) dan 492 kantor cabang konvensional yang menyediakan layanan syariah (office channeling). Jumlah jaringan kantor perbankan syariah per Februari 2011 sebanyak 1.824 buah, meningkat tajam dibandingkan tahun 2005 yang hanya memiliki 550.

Setiap tahun rata-rata jumlah jaringan kantor perbankan syariah tumbuh sebesar 47\% (Tribun Jabar, 21 Desember 2012). Selain menunjukkan layanan perbankan syariah, layanan non-perbankan juga mengalami kompetisi yang ketat, yaitu pada jenis layanan asuransi syariah, pembiayaan syariah, pegadaian syariah, dan layanan syariah yang berskup lecil yaitu baitul maal wat tamwil (BMT) sebagai lembaga keuangan mikro syariah yang berbadan hukum koperasi namun menerapkan prinsip-prinsip syariah.

Organisasi syariah yang didirikan bertujuan perjuangan menegakkan bisnis yang syariah dan memperjuangkan nasib ummat terutama rakyat kecil, selain melihat peluang bisnis di kalangan umat Islam juga dalam rangka mewujudkan fallah atau kesejahteraan bersama (Alma \& Priansa, 2009). Kesemua lembaga keuangan syariah juga menyadari betul persaingan antar lembaga baik dalam konteks berkooperasi dan berkompetisi dengan sesama lembaga keuangan jenis syariah, terutama juga terhadap lembaga keuangan non-syariah atau konvensional, sehingga berbagai upaya dilakukan untuk meraih posisi bukan hanya sekedar bertahan, melainkan untuk terus tumbuh dan berkembang.

Organisasi syariah tidak luput terjadi turn-over karyawan sebagai dampak alamiah suatu organisasi dengan level dan skup kecil di mana sebagian besar karyawan mencari penghasilan yang lebih besar dan karir yang tinggi. Selain itu didapatkan data bahwa pelayanan customer menjadi poin penting tercapainya target organisasi. Dengan demikian, komitmen organisasi merupakan salah satu kunci dalam ketercapaian produktivitas dan pemeliharaan organisasi.

Banyak literatur yang menunjukkan pengertian dan cakupan komitmen organisasi dalam beberapa sudut pandang. Meyer dan Allen (1997) menyatakan bahwa komitmen pada organisasi sebagai "a psychological state that (a) characterize the employee's relationship with the organization, and (b) has implicationsfor the decisions for continue membership in an organization". Diartikan bahwa komitmen organisasi merupakan status/kondisi psikologis yang menjadi karakteristik hubungan antara karyawan dengan organisasinya dan memiliki implikasi terhadap keputusannya untuk terus menjadi anggota organisasi.

Meyer dan Allen (1997) membagi komitmen organisasional menjadi tiga komponen, terdiri atas:

a. Komitmen kesinambungan (continuance commitment), merupakan suatu komitmen yang didasarkan atas kebutuhan rasional atau prinsip untung rugi. Komitmen di sini berkaitan kekhawatiran akan kehilangan apa yang telah didapat dari organisasi. Kunci dari komitmen ini, yaitu "want to" (keinginan dirinya). 
b. Komitmen normatif (normative commitment), merupakan komitmen yang didasarkan pada norma yang ada di dalam diri karyawan, dengan kata lain karyawan merasa harus bertahan karena loyalitas dan nilai-nilai moral yang dimiliki secara pribadi. Kunci dari komitmen ini ini, yaitu "ought to" (kewajiban untuk bertahan).

c. Komitmen afektif (affective commitment), merupakan suatu komitmen karena ingin terikat dengan organisasi, dengan kata lain berkaitan perasaan berkewajiban karyawan untuk stand by karena adanya persamaan nilai pribadi dan nilai organisasi. Kunci dari komitmen ini adalah "need to" (kebutuhan untuk bertahan).

Dalam konteks komitmen organisasional pada organisasi syariah, seorang karyawan diarahkan untuk berorientasi pada organisasi yang syar'i, bersedia menyumbangkan energinya dan mengikatkan diri melalui aktivitas dan keterlibatan untuk mencapai tujuan organisasi yang amanah sebagai bentuk aktualisasi diri sesuai aturan Allah SWT. Alma dan Priansa (2009) menyatakan bahwa kewajiban seorang muslim yaitu patuh, mengikuti apa yang digariskan oleh atasan, menepati janji dalam akad dan jujur dalam melaksanakan amanat.

Dalam penelitian ini penulis memodifikasi komponen komitmen organisasional Steers dan Porter (1997) yang memandang komitmen sebagai sesuatu yang bersifat afektif emosional dikaitkan dengan sifat afektif spiritual. Komitmen organisasional pada organisasi syariah memiliki tingkat kekuatan identifikasi karyawan terhadap organisasi syariah yang didasarkan pada tiga aspek, yaitu: (1) Suatu kepercayaan yang pasti dan penerimaan yang penuh atas nilai-nilai dan tujuan organisasi syariah; (2) Suatu keinginan untuk berusaha sekuat tenaga demi kepentingan kesyariahan organisasi; dan (3) Suatu dorongan dan keinginan yang kuat untuk berhubungan aktif terhadap perusahaan karena individu mempunyai keinginan untuk memberikan sesuatu dari dirinya sendiri untuk menyokong kesejahteraan organisasi syariah.

Salah satu yang berpengaruh dalam mencptakan komitmen, yaitu kemampuan mengelola diri agar memiliki visi yang sama dengan organisasinya (Robbins, 2005). Untuk itu para anggota suatu organisasi harus mampu mengelola dirinya agar bisa menjalankan perannya. Kemampuan mengelola diri ini diistilahkan sebagai selfregulation (regulasi diri).

Zimmerman (Bokaerts, dkk, 2000) menyatakan sebagai berikut: "selfregulation refers to self-generated thoughts, feelings, and actions that are planned and cyclically adapted to the attainment of personal goals". Di sini dinyatakannya bahwa regulasi diri menunjuk pada pikiran, perasaan, dan tindakan yang diprakarsai oleh diri yang direncanakan dan terus-menerus untuk disesuaikan dengan tujuan-tujuan pribadi yang ditetapkan.

Dalam teori dasarnya, secara terminologi regulasi diri didiskripsikan sebagai: "that is guided by metacognition (thinking about one's thinking), strategic action (planning, monitoring, and evaluating personal progress against a standard), and motivation" (Zimmerman, 1989, Boekaerts \& $\quad \mathrm{C} \circ \mathrm{rno}, \quad 2005, \mathrm{~d}$ a $\mathrm{n}$ http://en.wikipedia.org/). Dari konsep regulasi diri tersebut, aspek regulasi diri islami dengan mengakomodasi konsep regulasi muslim menurut Nurdin, dkk (2001) dan LPPI UMP (2009) yang oleh Wibowo (2011) dijabarkan terdiri dari: (1) pengarahan metakognisi sesuai akidah Islam, yaitu pemahaman dan kesadaran tentang proses kognitif, merencanakan, mengorganisasi, mengukur diri, dan menginstruksikan diri dalam kerangka keimanan; (2) pengarahan motivasi yang Islami $_{2}$ mencakup semua pemikiran, tindakan atau perilaku di mana seseorang berusaha memengaruhi pilihan, usaha, dan ketekunannya dalam rangka beribadah dan bermuamalah yang diwujudkan dalam bentuk dorongan berjuang di jalan Allah (jihad) dan dorongan untuk melakukan muamalah atau beramal soleh (amilussolihat); dan (3) pengarahan perilaku aktif sebagai Abdullah dan Khalifah.

Sementara itu regulasi diri semata 
belum cukup, menurut Guion (Blum, 1988), salah satu yang berperan dalam semangat kerja dan komitmen organisasi adalah sekumpulan sikap dari karyawan yang berhubungan dalam pekerjaannya. Seperti dinyatakan dalam penelitian adanya kesesuaian dengan pekerjaan, akan membuat karyawan dengan mudah dapat menyelesaikan pekerjaannya dengan baik, sebagaimana dinyatakan oleh Dunham (Muchinsky, 1987), bahwa terdapat hubungan positif antara tanggapan sifat-sifat tugas, syarat-syarat kemampuan dan nilai kerja.

Menurut Turner dan Lawrence (Luthans, 1985), karakteristik pekerjaan merupakan atribut-atribut tugas yang bersifat khusus yang ada dalam pekerjaan. Gibson, dkk (2000) menyebutkan bahwa karakteristik pekerjaan tersebut sebagai isi pekerjaan yang merupakan sifat-sifat umum pekerjaan yang dirasakan karyawan sebagai pemegang pekerjaan. Isi pekerjaan penting untuk membedakan antara sifat-sifat objektif dari suatu pekerjaan dan sifat-sifat subjektif dari suatu perusahaan seperti digambarkan dalam persepsi orang yang melaksanakannya, apakah ia merasa sesuai atau tidak dengan isi pekerjaan yang dilaksanakannya.

Menurut teori karakteristik pekerjaan ini, sebuah pekerjaan dapat melahirkan tiga keadaan psikologis dalam diri seorang karyawan, yakni mengalami makna kerja, memikul tanggung jawab akan hasil kerja, dan pengetahuan akan hasil kerja. Akhirnya, ketiga kondisi psikologis ini akan memengaruhi motivasi kerja secara internal, kualitas kinerja, kepuasan kerja, ketidakhadiran dan perputaran karyawan. Menurut Hackman dan Oldham (1980) serta Munandar (2001), keadaan psikologis kritis ini dipengaruhi oleh dimensi inti dari sebuah pekerjaan yang terdiri dari keragaman keahlian, identitas tugas, signifikansi tugas, otonomi tugas dan umpan balik.

Pekerja yang benar-benar melakukan pekerjaannya dengan baik harus mempersepsikan pekerjaannya, mengalami tanggung jawab nyata atas hasil pekerjaannya dan mengetahui hasilnya itu. Menurut Sims dkk (Hackman \& Oldham,
1980) untuk dapat mempunyai arti, pekerjaan harus mencakup variasi ketrampilan, identitas tugas, arti tugas, otonomi, umpan balik, tantangan dalam pekerjaan, kesepakatan dengan teman kerja dan kesempatan persahabatan. Masingmasing isi pekerjaan merupakan dimensidimensi inti pekerjaan yang tercakup dalam karakteristik jabatan akan menunjang kenyamanan dalam bekerja sehingga diharapkan bisa komitmen karyawan terhadap institusinya. Seperti ditunjukkan dari penelitian Purwaningsih (2008) bahwa terdapat ada hubungan positif yang sangat signifikan antara karakteristik pekerjaan dengan komitmen organisasi, dengan diperolehnya koefisien korelasi (r) sebesar 0,636 dengan $\mathrm{p}=0,000(\mathrm{p}<0,01)$ antara kedua variabel.

Berangkat dari pemaparan di atas, perlu untuk dilakukan penelitian tentang peran regulasi diri Islami dan karakteristik pekerjaan terhadap komitmen organisasi pada karyawan organisasi syariah. Berdasarkan masalah, tujuan, dan tinjuan pustaka di atas, maka penulis membuat hipotesis sebagai berikut: (1) ada pengaruh yang signifikan antara regulasi diri islami terhadap komitmen organisasional; (2) ada pengaruh yang signifikan antara karakteristik pekerjaan terhadap komitmen organisasional; dan (3) ada pengaruh yang signifikan antara regulasi diri islami dan karakteristik pekerjaan terhadap komitmen organisasional pada organisasi syariah.

\section{METODE PENELITIAN}

Penelitian ini menggunakan desain penelitian yang sifatnya merupakan penelitian kausal. Penelitian kausal merupakan penelitian yang bertujuan untuk membuktikan hubungan sebab akibat atau hubungan memengaruhi dan dipengaruhi dari variabel-variabel yang diteliti (Istijanto, 2005).

Penelitian ini tergolong penelitian kuantitatif berdasarkan jenis data dan prosedur menganalisis datanya. Penelitian kuantitatif adalah penelitian yang menggunakan rancangan penelitian berdasarkan prosedur statistik atau dengan cara lain dari kuantifikasi untuk mengukur 
variabel penelitian. Variabel independen dalam penelitian ini, yaitu regulasi diri islami dan karakteristik pekerjaan, sementara variabel dependen di penelitian ini yaitu: komitmen organisasional.

\section{Subjek}

Subjek dalam penelitian ini adalah para karyawan di BMT Dana Mentari Purwokerto. Sampel penelitian dilakukan secara random dan didapatkan 44 subjek penelitian yang memiliki ciri-ciri: pendidikan terakhir SLTA, masa kerja minimal 1 tahun dan usia minimal 18 tahun.

\section{Alat Ukur}

Skala yang digunakan untuk mengumpulkan data, yaitu: (1) Skala Regulasi Diri Islami yang terdiri dari 28 aitem meliputi aspek pengarahan metakognisi sesuai akidah Islam, pengarahan motivasi yang Islami, dan pengarahan perilaku aktif.; (2) Skala Karakteristik Pekerjaan yang meliputi 25 aitem dengan aspek: keragaman ketrampilan, jati diri tugas, signifikansi tugas, otonomi, dan umpan balik; dan (3) Skala Komitmen Organisasional, yang terdiri dari 25 aitem meliputi: komitmen afektif, komitmen kontinuansi, dan komitmen normatif.

\section{Teknik Analisis Data}

Uji hipotesis dengan analisis regresi ganda, yang dalam proses penghitungannya analisis data peneliti menggunakan program SPSS For Windows Release 17.00

\section{HASIL PENELITIAN}

\section{Deskripsi Data}

Untuk melakukan analisis ini digunakan metode analisis jalur regresi ganda. Sumber data diperoleh dari jawaban dari 44 responden yang dijadikan sampel yaitu para karyawan BMT Dana Mentari Purwokerto yang merupakan organisasi syariah dalam bentuk lembaga keuangan mikro jenis BMT yang terbesar di Kabupaten Banyumas.

\section{Hasil Analisis Data}

Berikut adalah temuan data hasil perhitungan dalam analisis regresi ganda dengan menggunakan program SPSS For Windows Release 17.00.

a. R atau koefisien korelasi

Tabel 1. Koefisien Korelasi

\begin{tabular}{|ll|l|l|l|}
\hline & & $\begin{array}{l}\text { Komitmen } \\
\text { Organisasi }\end{array}$ & $\begin{array}{l}\text { Regulasi } \\
\text { Diri islami }\end{array}$ & $\begin{array}{l}\text { Kharakte } \\
\text { Pekerjaan }\end{array}$ \\
\hline $\begin{array}{l}\text { Pearson } \\
\text { Correlation }\end{array}$ & $\begin{array}{l}\text { Komitmen } \\
\text { Organisasi } \\
\text { Regulasi } \\
\text { Diri islami } \\
\text { Kharakter } \\
\text { Pekerjaan }\end{array}$ & .624 & .624 & .324 \\
\hline Sig. (1-tailed) & $\begin{array}{l}\text { Komitmen } \\
\text { Organisasi } \\
\text { Regulasi } \\
\text { Diri islami } \\
\text { Kharakter } \\
\text { Pekerjaan }\end{array}$ & .0000 & .441 \\
\hline $\begin{array}{l}\text { Komitmen } \\
\text { Organisasi } \\
\text { Regulasi } \\
\text { Diri islami } \\
\text { Kharakter } \\
\text { Pekerjaan }\end{array}$ & 44 & .000 & 1.000 \\
\hline
\end{tabular}

Nilai $\mathrm{R}$ menerangkan tingkat hubungan antara regulasi diri Islami $\left(\mathrm{X}_{1}\right)$ dan karakteristik pekerjaan $\left(\mathrm{X}_{2}\right)$ dengan komitmen organisasional (Y). Dari hasil analisis didapat nilai koefisien korelasi $\mathrm{X}_{1}$ terhadap Y sebesar 0,624, berarti bahwa ada hubungan antara regulasi diri Islami dengan komitmen organisasional sebesar $62,4 \%$. Juga didapat nilai koefisien korelasi $\mathrm{X}_{2}$ terhadap Y sebesar 0,324, berarti bahwa ada hubungan antara karakteristik pekerjaan dengan komitmen organisasional sebesar $32,4 \%$.

b. Uji Model Linier

Tabel 2. Tabel Anova

\begin{tabular}{|c|l|l|l|l|l|}
\hline Model & $\begin{array}{l}\text { Sum of } \\
\text { Squares }\end{array}$ & $\mathrm{df}$ & $\begin{array}{l}\text { Mean } \\
\text { Square }\end{array}$ & $\mathrm{F}$ & Sig. \\
\hline 1 Regression & 2759.211 & 2 & 1379.605 & 13.245 & $.000^{\mathrm{a}}$ \\
Residual & 4270.516 & 41 & 104.159 & & \\
Total & 7029.727 & 43 & & & \\
\hline
\end{tabular}

Didapat nilai $\mathrm{F}$ hitung pada tabel ANOVA di atas, yaitu sebesar 13,245. Sementara itu $\mathrm{F}$ tabel pada taraf signifikansi $5 \%$ yaitu sebesar 3,82. Dari hasil di atas dapat dilihat bahwa $\mathrm{F}$ hitung $>\mathrm{F}$ tabel $(13,245>$ 
3,820), disimpulkan bahwa model liniear, $Y$ $=\mathrm{a}=\mathrm{bX}$ sudah tepat dan dapat digunakan. Dapat dilihat bahwa nilai probabilitas adalah $0,000<0,05$, berarti model diterima atau dapat disimpulkan bahwa bentuk persamaan linear $\mathrm{Y}=\mathrm{a}+\mathrm{bX}$ sudah tepat.

\section{c. Uji Hipotesis}

Tabel 3. Tabel Koefisien

\begin{tabular}{|l|c|c|c|c|c|}
\hline \multirow{2}{*}{ Model } & \multicolumn{2}{|c|}{$\begin{array}{c}\text { Unstandardized } \\
\text { Coefficients }\end{array}$} & $\begin{array}{c}\text { Standardized } \\
\text { Coefficients }\end{array}$ & \multirow{2}{*}{} & \\
\cline { 2 - 5 } & $\mathrm{B}$ & $\begin{array}{c}\text { Std. } \\
\text { Error }\end{array}$ & Beta & $\mathrm{t}$ & Sig. \\
\hline $\begin{array}{l}\text { 1 (Constant) } \\
\text { Regulasi }\end{array}$ & -14.652 & 21.343 & & -.687 & .496 \\
$\begin{array}{l}\text { Diri islami } \\
\text { Kharakter } \\
\text { Pekerjaan }\end{array}$ & .992 & .225 & .598 & $\begin{array}{c}4.40 \\
7\end{array}$ & .000 \\
& .093 & .211 & .060 & .442 & .661 \\
\hline
\end{tabular}

Uji hipotesis 1:

"ada pengaruh yang signifikan antara regulasi diri Islami terhadap komitmen organisasional"

Dilihat dari tabel koefisien di atas, hasil perhitungan pengaruh regulasi diri Islami $\left(\mathrm{X}_{1}\right)$ terhadap komitmen organisasional (Y) didapatkan hasil $\mathrm{t}_{\text {hitung }}$ sebesar 4,407. Sementara itu $\mathrm{t}$ tabel dengan tingkat signifikansi 0,05 dan derajat bebas $\mathrm{N}-2=$ 44-2 = 42 di mana dilakukan di dua sisi ( 2 tailed) di dapatkan $\mathrm{t}_{\text {tabel }}(1 / 20,05 ; 42)=$ 2,018. Karena $\mathrm{t}_{\text {hitung }}>\mathrm{t}_{\text {tabel, }}$, maka Ho ditolak, artinya bahwa regulasi diri Islami berpengaruh secara nyata (signifikan) terhadap komitmen organisasional.

Uji hipotesis 2:

"ada pengaruh yang signifikan antara karakteristik pekerjaan terhadap komitmen organisasional"

Dilihat dari tabel koefisien di atas, hasil perhitungan pengaruh karakteristik pekerjaan $\left(\mathrm{X}_{2}\right)$ terhadap komitmen organisasional (Y) didapatkan hasil $\mathrm{t}_{\text {hitung }}$ sebesar 0,442. Dengan hasil perhitungan $\mathrm{t}_{\text {tabel }}$ sebesar 2,018, maka $\mathrm{t}_{\text {hitung }}>\mathrm{t}_{\text {tabel }}$, dengan kesimpulan Ho diterima, artinya bahwa karakteristik pekerjaan tidak berpengaruh secara langsung (tidak signifikan) terhadap komitmen organisasional.
Uji hipotesis 3:

"ada pengaruh yang signifikan antara regulasi diri Islami dan karakteristik pekerjaan terhadap komitmen organisasional."

Tabel 4. Model Summary

\begin{tabular}{|l|c|c|c|c|}
\hline Model & $\mathrm{R}$ & $\begin{array}{c}\mathrm{R} \\
\text { Square }\end{array}$ & $\begin{array}{c}\text { Adjusted } \\
\text { R Square }\end{array}$ & $\begin{array}{c}\text { Std. Error } \\
\text { of the } \\
\text { Estimate }\end{array}$ \\
\hline 1 & $627^{\mathrm{a}}$ & .393 & .363 & 10.206 \\
\hline
\end{tabular}

Koefisien determinasi menerangkan seberapa variasi $\mathrm{Y}$ yang disebabkan oleh $\mathrm{X}_{1}$ dan $\mathrm{X}_{2}$ secara simultan. Dilihat dari tabel koefisien di atas, dapat dibaca nilai $\mathrm{R}$ square $\left(\mathrm{R}^{2}\right)$ sebesar 0,393, artinya bahwa kontribusi regulasi diri Islami dan karakteristik pekerjaan secara simultan yang langsung memengaruhi komitmen organisasional, yaitu R2 sebesar 39,3\%, sisanya sebesar $60,7 \%$ dipengaruhi oleh faktor-faktor lain di luar persamaan yang tidak dapat dijelaskan dalam penelitian ini.

\section{PEMBAHASAN}

Hasil uji hipotesis membuktikan bila regulasi diri islami berpengaruh secara langsung terhadap komitmen organisasional. Dalam konteks bagaimana seorang karyawan yang memiliki regulasi diri Islami, di mana dalam setting kerja seorang muslim "berangkat" dari pemikiran bahwa bekerja merupakan ibadah, cenderung mengarahkan diri seorang karyawan untuk loyal dan komit terhadap upaya bekerja secara syar'i apalagi diwadahi dalam suatu organisasi syariah. Korelasi antara kedua variabel dengan korelasi sebesar 0, 624 wajar ketika kontribusi regulasi diri Islami terhadap komitmen organisasional kemudian menunjukkan pengaruh yang positif dan signifikan.

Regulasi diri Islami sebagai kemampuan regulasi diri sesuai aturan agama Islam, dalam penerapannya pada seorang muslim dirinya akan meregulasi diri dengan cara mengaktivasi pemikiran, perasaan, dan perilaku dalam upaya mencapai tujuan personal yang telah 
ditetapkan untuk menjadi insan kamil sebagai tujuan seorang muslim taat. Regulasi diri tersebut mengarahkan aktivasi dirinya ke arah tujuan yang lebih tinggi, yaitu sebagai ibadah baik ibadah khusus maupun ibadah umum.

Penelitian Haryanto dan Sriwidodo (2009) membuktikan bahwa karakteristik personal, karakteristik kerja dan pengalaman kerja merupakan antesenden komitmen organisasi. Regulasi diri sebagai salah satu karakteristik personal pada konteks "self' mengatur diri untuk mengelola dirinya dalam bekerja dan bersikap terhadap institusinya. Hasil uji hipotesis membuktikan bila karakteristik pekerjaan kurang berpengaruh secara langsung terhadap komitmen organisasional. Hal ini sebagaimana diungkapkan oleh Gibson dkk (2000) bahwa karakteristik pekerjaan tersebut sebagai isi pekerjaan yang merupakan sifat-sifat umum pekerjaan yang dirasakan karyawan sebagai pemegang pekerjaan membutuhkan variable interverning misalnya kepuasan kerja.

Kepuasan kerja sebagai "the way an employee feels about his her job" menurut Wexley dan Yukl (Robbins \& Judge, 2007) menunjukkan bahwa karakteristik akan dirasakan bukan sekedar dipersepsi dan dilakukan menuntut suatu perasaan puas atas pekerjaan yang diembannya. Menurut Organ (Gibson, dkk, 2000), kepuasan kerja akan membuat karyawan memberikan yang terbaik bagi organisasi. Isi pekerjaan penting untuk membedakan antara sifat-sifat objektif dari suatu pekerjaan dan sifat-sifat subjektif dari suatu perusahaan seperti digambarkan dalam persepsi orang yang melaksanakannya, apakah ia merasa sesuai atau tidak dengan isi pekerjaan yang dilaksanakannya.

Secara keseluruhan penelitian ini belum menggali faktor yang memungkinkan memiliki kontribusi pengaruh terhadap komitmen organisasional terutama pada organisasi syariah. Faktor organisasi seperti iklim kerja, budaya organisasi, dan persepsi terhadap lingkungan kerja sebagai bagian dari pengalaman selama bekerja akan memengaruhi bagaimana seorang karyawan menjalankan pekerjaannya dan bersedia memberikan yang terbaik dalam pekerjaannya. Pengaruh regulasi diri Islami dan karakteristik pekerjaan secara simultan dan langsung memengaruhi variabel komitmen organisasional "hanya" sebesar $39,3 \%$, menunjukkan masih ada peran yang besar sejumlah $60,7 \%$ sebagai faktor lain di luar variabel yang dibahas dalam penelitian ini.

Penggunaan teori komitmen organisasional yang dikemukakan Allen dan Meyer (1997) barangkali perlu ditinjau ulang dalam konteks komitmen terhadap organisasi syariah, terutama cakupan dimensi komitmen kontinuitas sebagai keinginan untuk berkesinambungan diakibatkan keuntungan yang didapat dari perusahaan menjadi tidak relevan dengan konsep seorang muslim dalam bekerja, yaitu bekerja merupakan ibadah, apalagi ketika bekerja di organisasi syariah. Perlu dipertimbangkan penggunaan teori komitmen organisasi lain, yaitu teori komitmen organisasi Steers dan Porter (1991) yang lebih merujuk pada dimensi komitmen afektif sebagai aspek utama dalam komitmen organisasi, sehingga komitmen organisasi di sini digambarkan oleh Steers dan Porter dan Gibson, dkk (2001) dengan menguraikan pendapat Buchanan digambarkan sebagai berikut: bahwa komitmen organisasi melibatkan tiga sikap, yaitu: (1) identifikasi dengan tujuan organisasi (2) perasaan keterlibatan dalam tugas-tugas organisasi dan (3) perasaan loyalitas terhadap organisasi.

\section{SIMPULAN DAN SARAN}

\section{Simpulan}

Dari penelitian ini secara umum didapatkan hasil bahwa: (1) ada pengaruh yang signifikan antara regulasi diri islami terhadap komitmen organisasional; (2) tidak ada pengaruh yang signifikan antara karakteristik pekerjaan terhadap komitmen organisasional; dan (3) ada pengaruh yang signifikan antara regulasi diri islami dan karakteristik pekerjaan terhadap komitmen organisasional. 


\section{Saran}

Sebagai saran, bahwa perlu dikembangkan penelitian yang lebih luas, mengkaitkan dengan variabel lain, seperti seperti iklim kerja, budaya organisasi, dan persepsi terhadap lingkungan kerja psikososial, selain juga melibatkan karakteristik individu yang lain seperti kepribadian dan citra diri, dan sebagainya. Populasi atau sampel yang digunakan hendaknya dikenakan pada berbagai jenis lembaga keuangan syariah atau bahkan pada organisasi non-syariah, sehingga memberikan gambaran yang lebih komprehensif mengenai peran komitmen organisasional pada organisasi syariah dan regulasi diri secara islam dalam aplikasinya pada karyawan muslim.

\section{Bibliografi}

Tim Penerjemah Al Qur'an. (2000). Alqur'an dan terjemahannya. Jakarta: Departemen Agama RI.,

Allen, J.P., dan Meyer, J.A. (1997). Commitment in the workplace: Theory, research, and application. California: SAGE Publications, Inc.

Alma, B. \& Priansa, D.J. (2009). Manajemen bisnis syariah. Bandung: Penerbit Alfbeta

Boekaerts, M., Pintrich, P., \& Zeidner, Mosche. (2000). Handbook of self regulation. California: Academic Press

Djastuti, I. (2011). Pengaruh karakteristik pekerjaan terhadap komitmen organisasi karyawan tingkat managerial perusahaan jasa konstruksi di Jawa Tengah. Jurnal Bisnis dan Akuntansi. Fakultas Ekonomi Universitas Dipnegoro Semarang. 13 (1), 1-19.

Ghufron, M.N \& Risnawita, R.S. (2010). Teori-teori psikologi. Yogyakarta: Arus Media Group
Gibson, J.L., Ivancevich, J.M. \& Donnelly, J.H. (2000). Organisasi dan manajemen (Djoerban Wahid, Penerj). Jakarta: Erlangga

Hackman, J. \& Oldham, G. (1980). Work redesign. Massachusstes: AddisonWesley

Haryanto, T. \& Sriwidodo, U. (2009). Pengaruh karakteristik personal, karakteristik kerja dan pengalaman kerja terhadap komitmen organisasi. e-Journal Manajemen Sumber Daya Manusia. 3, (1), $17-$ 24.

LPPI UMP. (2009). Membangun intelektual muslim yang tangguh. Tidak diterbitkan. Purwokerto: Lembaga Pengkajian dan Pengamalan Islam Universitas Muhammadiyah Purwokerto

Muchinsky, P.M. (1987). Psychology applied to work. Chicago: The Dorsey Press

Mustofa. (1997). Dasar-dasar Islam. Bandung: Angkasa

Nurdin, M. dan tim. (2001). Moral dan kognisi Islam (buku teks Agama islam untuk perguruan tinggi umum). Bandung: Alfabeta

Purwaningsih, I. (2008). Hubungan antara karakteristik pekerjaan dengan komitmen organisasi. Skripsi, tidak diterbitkan. Surakarta: Universitas Muhammadiyah Surakarta.

Republika, (20 Mei 2010). Pertumbuhan bank syariah di Purwokerto mengesankan.

Robbins, S.P. \& Judge. (2007). Perilaku organisasi (Hadyana Pujaatmaka, Penerj). Jakarta: Salemba Empat

Sopiah. (2008). Perilaku organisasi. Yogyakarta: PenerbitAndi 
Steers, R.M. \& Porter, L.W. (1991). Motivation and work behavior. Fifth Edition. New York: Mc. Grawhill International Edition

Wibowo, U.D.A. (2000). Hubungan antara kesesuaian karyawan terhadap karakteristik pekerjaan dan semangat kerja. Skripsi, tidak diterbitkan. Surakarta: Universitas Muhammadiyah Surakarta

Wibowo, U.D.A. (2011). Peran regulasi diri secara Islam dan komitmen organisasional pada organisasi Syariah terhadap organizational citizenship behavior (OCB) pada karyawan bank syariah X cabang Purwokerto. Tesis, tidak diterbitkan. Bandung: Universitas Padjajaran
Zimmerman, B.J. (1989). A social cognitive view of self regulated academic learning. Jurnal of Educational Psychology, 81,329-339.

\section{Sumber Internet}

Islam. Wikipedia. Diunduh pada 20 Februari 20013 , $\mathrm{d}$ a $\mathrm{r}$ i http://id.wikipedia.org/wiki/Islam

Self Regulation. Diunduh pada 10 Februari 2013, dari http://en.wikipedia.org/wiki/Selfregulated_learning 